\title{
HUBUNGAN ANTARA DUKUNGAN SOSIAL DENGAN TINGKAT STRES ORANG TUA DENGAN ANAK PENDERITA AUTISME
}

\author{
Rani Dwi Hapsari ${ }^{1}$, Asri Mutiara Putri ${ }^{2}$, Dita Fitriani ${ }^{3}$ \\ ${ }^{13}$ Prodi Pendidikan Dokter, Fakultas Kedokteran, Universitas Malahayati \\ ${ }^{2}$ Prodi Psikologi Fakultas Kedokteran, Universitas Malahayati \\ ranidwihapsari01@gmail.com, asri.mp@gmail.com
}

\begin{abstract}
Parents with autism children face challenges placing them at risk for high levels of stress. Social support might decrease the negative impact of stress. Purpose of this study to analyze the correlation between social support and the stress level on parents of children with autism disorder. Method using in this study is survey analytical with cross-sectional study. The sampling technique used is the accidental sampling. The sample included 39 parents of autism children in special school at Bandar Lampung. Social support in parents was measured through social support scale and stress levels was measured through Perceived Stress Scale 10. Rank Spearman-rho correlation was used to analyze. Result of this study found that parents having low stress levels $(59,0 \%)$ and getting high social support $(61,5 \%)$. The result of Rank Spearman-Rho test is $r=0,992$ and $\mathrm{p}=0,000$. This result proved there are significant correlation between social support and stress levels on parents of autism children
\end{abstract}

Keyword: Autism Disorder, Social Support, Stress Levels, Parents, SLB

\begin{abstract}
ABSTRAK
Orang tua dari anak autis menghadapi tantangan yang menempatkan mereka pada risiko stres tingkat tinggi. Dukungan sosial dapat menurunkan dampak negatif dari stres. Penelitian ini untuk mengetahui hubungan antara dukungan sosial dengan tingkat stres orang tua dari anak autis. Jenis penelitian survei analitik dengan pendekatan cross-sectional.Teknik pengambilan sampel adalah teknik accidental sampling. Sampel dalam penelitian yaitu orang tua anak autis di SLB Bandarlampung sebanyak 39 orang. Dukungan sosial pada orang tua diukur dengan skala dukungan sosial dan tingkat stres diukur dengan skala Perceived Stress Scale 10. Teknik analisis data untuk menguji hipotesis yaitu uji korelasi Rank Sperman-Rho. Penelitian ini menunjukkan bahwa orang tua dari anak autis memiliki tingkat stres rendah $(59,0 \%)$ dan dukungan sosial tinggi (61,5\%). Hasil uji Rank Spearman-Rho didapatkan nilai $\mathrm{r}=0,992$ dan $\mathrm{p}=0,000$. Terdapat hubungan yang signifikan antara dukungan sosial dengan tingkat stres orang tua dari anak autis.
\end{abstract}

Kata kunci: Gangguan Autis, Dukungan Sosial, Tingkat Stres, Orang tua, SLB 


\section{PENDAHULUAN}

Autis adalah gangguan perkembangan yang kompleks, meliputi gangguan perkembangan komunikasi, perilaku, kemampuan sosialisasi, sensoris, dan belajar yang disebabkan oleh adanya kerusakan otak. Biasanya, gejala sudah mulai tampak pada anak berusia dibawah 3 tahun (Soendari, 2016).

Menurut data dari United Nations Education Scientific and Cultural Organization(UNESCO) pada tahun 2011, terdapat 35 juta orang penyandang autis di dunia. Ratarata 6 dari 1000 orang di dunia telah mengidap autis. Autis dapat terjadi pada semua kelompok masyarakat kaya, miskin, di desa, kota, berpendidikan, maupun tidak, serta semua kelompok etnis dan budaya di dunia (Suryati \& Rahmawati, 2016). Sedangkan berdasarkan data World Health Organization (WHO), prevalensi autis di Indonesia mengalami peningkatan yang pesat dibandingkan 10 tahun yang lalu, yakni dari 1 per 1000 penduduk menjadi 8 per 1000 penduduk. Angka ini bahkan melampaui rata-rata dunia yaitu 6 per 1000 penduduk. Jumlah anak penyandang autis di Indonesia masih belum terdata dengan baik. Satu-satunya rujukan hanya berdasarkan rilis data pemerintah pada tahun 2015, yakni dikisarkan 112 ribu jiwa, itu pun masih bersifat asumsi (Ladyani \& Silaban, 2017).

Autis masih menjadi mimpi buruk bagi sebagian besar orang tua. Beberapa orang tua langsung merasa stres saat mendengar anaknya didiagnosis autis (Suryati \& Rahmawati, 2017). Mengasuh anak autis membutuhkan kesabaran ekstra karena banyaknya permasalahan perilaku, seperti tantrum, repetitif dan agresif. Selain itu, orang tua juga harus menghadapi stigma dari masyarakat mengenai anak penyandang autis (Fitriani \& Ambarini, 2013). Banyak masyarakat luas yang belum mengetahui tentang autis. Masyarakat beranggapan bahwa anak autis adalah anak-anak yang aneh, ada juga yang beranggapan bahwa autis adalah penyakit menular. Sebagian masyarakat bahkan tidak menerima dan mengakui keberadaan anak-anak autis ini. Penolakan terhadap anak-anak autis terlihat ketika mereka sulit diterima di lingkungan sebagaimana anak- 
anak lainnya. Hal ini yang dihadapi orang tua dan menjadi beban yang menyebabkan stres pada diri orang tua (Ginting, 2013).

Stres merupakan keseluruhan proses yang meliputi stimulasi, kejadian, peristiwa, respon, dan interprestasi individu yang menyebabkan timbulnya ketegangan di luar kemampuan seseorang untuk mengatasinya. Stres memiliki dua dampak, pertama stres secara fisik yaitu sistem kekebalan tubuh mengalami penurunan sehingga seseorang mudah terserang penyakit dan yang kedua secara psikis yaitu timbulnya perasaan negatif. Perasaan negatif ini akan menjadikan mereka mudah murung, kesepian, sedih, dendam, benci dan merasa tidak berguna. Pada tahap selanjutnya kondisi ini dapat memunculkan keputusasaan yang menjurus pada tindakan nekat bunuh diri (Kusumastuti, 2014).

Kondisi stres yang dialami ibu dapat menyebabkan ibu tidak dapat mengasuh anaknya dengan baik. Adanya dukungan sosial dapat mengurangi kondisi tersebut (Nugroho,2013). Dukungan sosial merupakan faktor penting dalam mengasuh anak dengan gangguan autis. Dukungan sosial mengacu pada kenyamanan, perhatian, penghargaan atau ketersedian bantuan kepada seseorang dari orang lain atau suatu kelompok (Pradana \& Kustanti, 2018). Sumber utama dukungan sosial adalah dukungan yang berasal dari anggota keluarga, teman dekat, rekan kerja, saudara dan tetangga. Dukungan sosial dapat mengubah hubungan antara respon individu terhadap kejadian yang dapat menimbulkan stres dan stres itu sendiri, memengaruhi strategi untuk mengatasi stres dan dengan begitu memodifikasi hubungan antara kejadian yang menimbulkan stres dan efeknya (Nugroho,2013).

Kasmayati (2013) mengatakan bahwa dukungan sosial dalam bentuk motivasi, perhatian dan nasihat dapat membantu individu berpikir positif, sehingga mampu mengubah individu yang pesimis menjadi optimis. Penyataan tersebut didukung dengan hasil penelitian Yasin dan Dzulkifli (2011) dimana dukungan sosial merupakan elemen yang membantu individu mengurangi pengalaman penuh stres dan mengatasinya. Hasil penelitian lain yang dilakukan oleh 
Twistiandayani dan Handika (2015) bahwa semakin baik dukungan yang diberikan keluarga terhadap ibu yang memiliki anak autis maka semakin positif penerimaan ibu terhadap anak.

Berdasarkan latar belakang tersebut, maka peneliti tertarik untuk melakukan penelitian mengenai "Hubungan Dukungan Sosial dengan Tingkat Stres Orang tua dari Anak Autis di SLB Bandarlampung”.

\section{METODE PENELITIAN}

Penelitian ini menggunakan metode survei analitik dengan pendekatan cross- sectional. Penelitian dilakukan pada bulan Januari dan Februari 2019 di SLB se-Bandarlampung, provinsi Lampung, Indonesia. Sampel sebanyak 39 orang tua dari anak autis yang diambil dengan teknik accidental sampling. Pengambilan data dilakukan dengan menyebarkan kuesioner. Kuesioner yang digunakan yaitu kuesioner dukungan sosial dan kuesioner Perceived Stress Scale 10 (PSS$10)$.

\section{HASIL PENELITIAN}

Berdasarkan analisis yang telah dilakukan sebelumnya, maka diperoleh hasil seperti tabel dibawah ini:

\section{Tabel 1. Distribusi Frekuensi Karakteristik Orang Tua dari Anak Autis Berdasarkan Dukungan Sosial di SLB se-Bandarlampung Tahun 2019}

\begin{tabular}{ccc}
\hline Dukungan Sosial & Jumlah & Persentase (\%) \\
\hline Rendah & 2 & 5,1 \\
Sedang & 13 & 33,3 \\
Tinggi & 24 & 61,5 \\
\hline Total & 39 & 100.0 \\
\hline
\end{tabular}

Berdasarkan tabel 1 diketahui bahwa sebagian besar responden mendapatkan dukungan sosial tinggi yaitu sebanyak 24 orang dengan persentase $(61,5 \%)$, sedangkan responden dengan dukungan sosial rendah sebanyak 2 orang dengan persentase $(5,1 \%)$. 
Tabel 2. Distribusi Frekuensi Orang Tua dari Anak Autis Berdasarkan Aspek Dukungan Sosial di SLB se-Bandarlampung Tahun 2019.

\begin{tabular}{ll}
\hline Aspek Dukungan Sosial & Mean \\
\hline Dukungan Emosional & 128,5 \\
\hline Dukungan Instrumen & 130,0 \\
\hline Dukungan Penghargaan & 114,5 \\
\hline Dukungan Informatif & 121,3 \\
\hline Total & 494,3 \\
\hline
\end{tabular}

Berdasarkan tabel 2 diketahui bahwa aspek dukungan sosial yang paling banyak didapat responden yaitu aspek dukungan instrumen dengan mean $(130,0)$, sedangkan paling sedikit aspek dukungan penghargaan dengan rata-rata $(114,5)$.

Tabel 3. Distribusi Frekuensi Orang Tua dari Anak Autis Berdasarkan Tingkat Stres di SLB se-Bandarlampung Tahun 2019

\begin{tabular}{ccc}
\hline Tingkat Stres & Jumlah & Presentase (\%) \\
\hline Ringan & 23 & 59,0 \\
\hline Sedang & 14 & 35,9 \\
\hline Berat & 2 & 5,1 \\
\hline Total & 39 & 100 \\
\hline
\end{tabular}

Berdasarkan tabel 3 diketahui bahwa sebagian besar responden dengan tingkat stres ringan yaitu sebanyak 23 orang dengan persentase $(59,0 \%)$, sedangkan responden dengan tingkat stres berat sebanyak 2 orang dengan persentase $(5,1 \%)$.

Tabel 4. Distribusi Frekuensi Orang Tua dari Anak Autis Berdasarkan Dimensi Tingkat Stres di SLB se-Bandarlampung Tahun 2019

\begin{tabular}{cc}
\hline Dimensi Stres & Mean \\
\hline Perasaan Tidak Terprediksi & 58,2 \\
\hline Perasaan Tidak Terkontrol & 51,6 \\
\hline Perasaan Tertekan & 55,6 \\
\hline
\end{tabular}




\section{Total} 165,4

Berdasarkan tabel 4 diketahui bahwa dimensi stres tertinggi yaitu perasaan tidak terprediksi dengan mean $(58,2)$, sedangkan dimensi tingkat stres terendah yaitu perasaan tertekan dengan mean $(55,6)$.

Tabel 5. Hubungan Dukungan Sosial dengan Tingkat Stres Orang Tua dari Anak Autis SLBse- Bandarlampung Tahun 2019.

\begin{tabular}{lcccccc}
\hline \multirow{1}{*}{ Variabel } & N & \multicolumn{3}{c}{ Tingkat Stres } & $\begin{array}{c}\text { p } \\
\text { value }\end{array}$ & r \\
\cline { 2 - 5 } & & Ringan & Sedang & Berat & \\
\hline $\begin{array}{l}\text { Dukungan Sosial } \\
\text { Rendah }\end{array}$ & 39 & $0 \%$ & $0 \%$ & $5,1 \%$ & & \\
\hline $\begin{array}{l}\text { Dukungan Sosial } \\
\text { Sedang }\end{array}$ & 39 & $2,6 \%$ & $30,8 \%$ & $0 \%$ & 0,000 & $-0,992$ \\
\hline $\begin{array}{l}\text { Dukungan Sosial } \\
\text { Tinggi }\end{array}$ & 39 & $59,0 \%$ & $2,6 \%$ & $0 \%$ & & \\
\hline \multicolumn{1}{c}{ Total } & $61,5 \%$ & $33,3 \%$ & $5,1 \%$ & & \\
\hline
\end{tabular}

Berdasarkan tabel 5 didapatkan nilai $p$ value sebesar $0,000(<0.05)$ yang menunjukkan bahwa terdapat hubungan yang bermana antara dukungan sosial dengan tingkat stres orang tua dari anak autis. Berdasarkan angka koefisien korelasi yang bertanda negatif, hal ini menunjukkan adanya arah hubungan yang berlawanan arah. Artinya semakin tinggi dukungan sosial yang didapat maka semakin rendah tingkat stres yang dialami orang tua dari anak autis.

Kemudian untuk tabulasi silang dapat dilihat bahwa responden dengan dukungan sosial tinggi mengalami stres ringan sebesar $(59,0 \%)$, dan stres sedang sebesar $(2,6 \%)$. Responden dengan dukungan sosial sedang mengalami stres ringan sebesar $(2,6 \%)$, dan stres sedang sebesar $(30,8)$. Responden dengan dukungan sosial rendah mengalami stres berat sebesar $(5,1 \%)$. 


\section{DISKUSI}

Berdasarkan analisis variabel dukungan sosial dalam tabel 1 didapatkan bahwa sebagian besar orang tua dari anak autis di SLB Bandarlampung memiliki dukungan sosial tinggi yaitu sebanyak 27 responden $(69,2)$ dan dukungan sosial rendah yaitu sebanyak 2 responden $(5,1)$. Individu yang memiliki dukungan sosial tinggi memiliki seseorang yang menyediakan solusisolusi atas permasalahannya, meyakinkan individu bahwa masalah dapat diatasi, dan mengingatkan individu untuk melihat sisi positif dalam kehidupannya. Sedangkan individu yang memiliki dukungan sosial rendah lebih kecil kemungkinannya untuk memiliki keunggulan, sehingga mereka mengalami dampak negatif dari stres yang dialami (Sarafino \& Smith, 2011).

Dukungan sosial dibagi menjadi beberapa aspek yaitu dukungan emosional, dukungan penghargaan, dukungan instrumen dan dukungan informatif. Dari hasil penelitian pada tabel 2 didapatkan aspek tertinggi adalah aspek dukungan instrumen dengan skor rata-rata $(130,0)$. Dukungan instrumen merupakan dukungan berupa bantuan langsung yang diberikan oleh seseorang ketika orang tua dari anak autis membutuhkan bantuan, baik berupa barang, jasa, maupun uang (Supriati \& Selvitriana, 2018). Faktor yang mempengaruhi dukungan instrumen salah satunya adalah faktor sosioekonomi. Semakin tinggi tingkat ekonomi seseorang, akan lebih cepat tanggap memberikan dukungan instrumen kepada individu yang mengalami kesulitan sehingga dukungan tersebut dapat menambah semangat dan mengurangi stres pada individu tersebut (Hlebec, Mrzel\& Kogovsek, 2009).

Aspek dukungan sosial terendah pada tabel 2 adalah aspek penghargaan dengan skor ratarata $(114,5)$. Dukungan penghargaan merupakan suatu bentuk ungkapan positif yang diberikan dengan cara menghargai, mendorong, dan menyetujui terhadap suatu ide, gagasan, atau kemampuan yang dimiliki seseorang. Dukungan penghargaan ini penting bagi orang tua dari anak autis untuk mengembalikan rasa percaya diri mereka dalam berinteraksi di tengah-tengah 
lingkungan sosial. Stigma dan diskriminasi di dalam lingkungan sosial mempengaruhi individu mendapat dukungan penghargaan yang rendah (Supriati \& Selvitriana, 2018).

Berdasarkan analisis variabel tingkat stres pada tabel 3 didapatkan bahwa sebagian besar orang tua yang memiliki anak autis di SLB Bandarlampung memiliki tingkat stres dalam kategori ringan yaitu sebanyak 23 responden $(59,0 \%)$. Tingkat stres dalam kategori ringan sering terjadi dalam kehidupan sehari-hari. Kondisi ini dapat membantu individu menjadi lebih waspada dan mencegah kemungkinan yang akan terjadi. Pada respon perilaku didapatkan semangat kerja berlebihan, mudah lelah dan tidak bisa santai. Stres ringan tidak akan menimbulkan penyakit kecuali jika dihadapi terus menerus (Atziza, 2015).

Tingkat stres terbagi menjadi tiga dimensi yaitu dimensi perasaan tidak terprediksi, perasaan tidak terkontrol dan perasaan tertekan. Dari hasil penelitian didapatkan dimensi tertinggi pada tabel 4 yaitu dimensi perasaan tidak terprediksi dengan skor rata-rata $(58,2)$. Dimensi perasaan tidak terprediksi yaitu ketika individu tidak mampu memprediksi peristiwa yang terjadi dalam kehidupannya secara tiba-tiba, maka individu tersebut akan menjadi tidak berdaya dan merasa putus asa sehingga hal ini yang mengakibatkan munculnya stres (Utami, 2016).

Dimensi stres yang paling rendah pada tabel 4 adalah dimensi perasaan tidak terkontrol dengan rata-rata $(51,6)$. Dimensi perasaan tidak terkontrol yaitu orang tua tidak mampu mengendalikan diri atas berbagai tuntutan eksternal termasuk lingkungan sehingga memberikan efek pada perilaku orang tua tersebut yang dapat menyebabkan stres (Utami, 2016).

Berdasarkan tabel 5 pada penelitian ini menunjukkan bahwa terdapat hubungan negatif yang signifikan antara dukungan sosial dengan tingkat stres orang tua. Hal tersebut dapat dilihat dari nilai koefisien korelasi sebesar $-0,992$ dengan nilai signifikansi $p=0,000<0,05$. Korelasi negatif tersebut menunjukkan bahwa semakin tinggi dukungan sosial maka semakin rendah tingkat stres pada orang tua yang memiliki anak autis atau sebaliknya. Berdasarkan hasil tersebut, dapat disimpulkan bahwa hipotesis yang diajukan pada penelitian ini diterima. 
Hal tersebut sesuai dengan pendapat Kusrini dan Prihartanti (2014) bahwa dukungan sosial merupakan suatu keadaan yang bermanfaat yang diperoleh dari anggota keluarga, teman, maupun kerabat yang dapat memberikan bantuan bagi individu dalam mengatasi dan menghadapi suatu permasalahan. Andharini dan Nurwidawati (2015) juga menjelaskan bahwa individu yang memiliki dukungan sosial yang tinggi akan memiliki penghargaan diri yang tinggi sehingga tidak mudah untuk mengalami stres.

Stres memang dibutuhkan oleh individu dalam derajat tertentu agar tetap sehat. Akan tetapi apabila stres melewati batas optimal penerimaan tubuh, stres dapat menyebabkan dampak buruk bagi kesehatan individu dan dapat pula menimbulkan penyakit. Oleh sebab itu perlu adanya penanganan agar stres tidak semakin meningkat. Penanganan stres dapat diberikan dengan adanya dukungan sosial. Hubungan yang bersifat support atau dukungan yang berasal dari lingkungan dapat meredamkan efek stres, membantu individu mengatasi stres dan mendapatkan kesehatan yang lebih baik.

Penelitian ini sejalan dengan penelitian yang dilakukan oleh Rahmawati, Machmuroch, dan Nugroho (2013) pada ibu yang memiliki anak autis di SLB di Surakarta menemukan bahwa terdapat hubungan yang signifikan antara dukungan sosial dengan tingkat stres. Dalam penelitian tersebut dijelaskan bahwa ibu yang memperoleh dukungan sosial dari lingkungannya akan memiliki kemampuan untuk bertahan dalam situasi yang penuh tantangan dan hambatan. Hasil penelitian ini juga sejalan dengan penelitian yang dilakukan oleh Kusumastuti (2014) bahwa orang tua dengan anak gangguan autis memiliki tingkat stres yang rendah dengan adanya dukungan sosial yang tinggi. Noor, Indriati dan Elita (2014) juga menjelaskan bahwa ibu yang memiliki anak autis dapat dibedakan tingkatan stres dari dukungan yang diperoleh, dimana ibu yang memperoleh dukungan sosial dari lingkungan sekitar memiliki tingkatan stres yang lebih ringan terkait masalah somatik dan gejala depresi daripada ibu yang tidak mendapatkan dukungan dari lingkungan sekitar. 


\section{KESIMPULAN DAN SARAN}

Distribusi frekuensi dukungan sosial pada orang tua yang memiliki anak autis paling banyak mendapat dukungan sosial tinggi yaitu sebanyak 24 responden $(61,5 \%)$. Distribusi frekuensi tingkat stres orang tua yang memiliki anak autis paling banyak tingkat stres kategori ringan yaitu sebanyak 23 responden (59\%). Berdasarkan karakteristik responden, usia dengan persentase terbanyak yaitu 36-45 tahun (48,7\%), jenis kelamin terbanyak yaitu perempuan (71,8\%), tingkat pendidikan terbanyak yaitu pendidikan menengah $(41,0 \%)$ dan pekerjaan terbanyak yaitu tidak bekerja $(71,8 \%)$. Terdapat hubungan yang signifikan antara dukungan sosial dengan tingkat stres orang tua dari anak autis dengan hasil p value $=0,000(<0,05)$ dengan arah hubungan negatif atau berlawan arah. Hal ini dapat diartikan bahwa semakin tinggi dukungan sosial maka semakin rendah tingkat stres. Penelitian selanjutnya diharapkan mampu menganalisis lebih lanjut faktorfaktor lain yang dapat mempengaruhi tingkat stress orang tua dengan anak autis.

\section{DAFTAR PUSTAKA}

Atziza, R. (2015). Faktor-Faktor yang Mempengaruhi Kejadian Stres dalam Pendidikan Kedokteran. Jurnal Agromedicine, 2(3), pp.317-320.

Fitriani, A \& Ambarini, T.K. (2013). Hubungan antara Hardiness dengan Tingkat Stres Pengasuhan pada Ibu dengan Anak Autis. Jurnal Psikologi Klinis dan Kesehatan Mental, 2(2).

Ginting, B.M., (2014). Respon Orangtua Siswa Penyandang Autis terhadap Pelayanan Pendidikan di Sekolah Alam Medan. Welfare StatE, 2(2).

Hlebec, V., Mrzel, M \& Kogovšek, T. (2009). Social Support Network and Received Support at Stressful Events. Advances in Methodology \& Statistics/Metodoloski zvezki, 5(1).

Kasmayati, K. (2013). Optimisme Remaja Penyandang Cacat Akibat Kecelakaan. EMPATHY Jurnal Fakultas Psikologi, 2(1).

Kusrini, W \& Prihartanti, N. (2014). Hubungan Dukungan Sosial dan Kepercayaan Diri dengan Prestasi Bahasa Inggris Siswa Kelas VIII SMP Negeri 6 Boyolali. Jurnal Penelitian Humaniora, 15(2), pp.131-140.

Kusumastuti, A.N. (2014). Stres Ibu Tunggal yang Memiliki Anak Autis. Jurnal Ilmiah Psikologi, 7(2).

Ladyani, F. \& Silaban, F.V. (2017). Analisis Peranan Terapis Terhadap Perkembangan Bahasa pada Pasien Autisme di Rumah Sakit Umum Daerah Dr. H. Abdul Moeloek Bandar Lampung. Jurnal Ilmu Kedokteran dan Kesehatan, 4(2). 
Nugroho, A.A. (2013). Hubungan antara Penerimaan Diri dan Dukungan Sosial dengan Stres pada Ibu yang Memiliki Anak Autis di SLB Autis di Surakarta. Jurnal Ilmiah Psikologi Candrajiwa, 2(2).

Pradana, A.P. \& Kustanti, E.R. (2018). Hubungan Antara Dukungan Sosial Suami Dengan Psychological Well-being Pada Ibu Yang Memiliki Anak Autisme. Empati, 6(2), pp.83-90.

Sarafino, E \& Smith, T. (2011). Health psychology biopsychosocial interaction. United State Of Amerika: John Wlley \& Sons.

Soendari, T. (2016). Penyandang Autis Dalam Isu Global (Sebuah Pengantar menuju Model Konseling yang Efektif di Sekolah). JASSI ANAKKU, 12(1), pp.87-96.

Supriati, L. \& Selvitriana, D.R. (2018). The Relationship of Family Support with Self-Esteem Level in People Living with HIV/AIDS (PLWHA) in Sadar Hati Foundation Malang. Journal Nursing Care and Biomolecular, 3(1), pp.6-14.

Suryati, S. \& Rahmawati, R. (2017). Pengaruh Terapi Bermain Terhadap Interaksi Sosial Anak Autis Di Sdlb Prof. Dr. Sri Soedewi Masjchun Sofwan, Sh Jambi Tahun 2014. Jurnal Ilmiah Universitas Batanghari Jambi, 16(1), pp.142-147.

Twistiandayani, R \& Handika, S.R. (2015). Hubungan Dukungan Keluarga Dengan Penerimaan Diri Ibu yang Mempunyai Anak Autis (Correlation Family Support with Self-Acceptance of Mother Who Have Children with Autism). Journals of Ners Community, 6(2), pp.143-149.

Utami, R.D. (2016). Pengaruh Humor Terhadap Penurunan Tingkat Stres Mahasiswa Psikologi Yang Mengerjakan Skripsi Di Universitas Negeri Semarang: Desertasi Universitas Negeri Semarang

Yasin \& Dzulkifli, M.A. (2011). Differences in Depression, Anxiety and Stress Between Low-and High-Achieving Students. Journal of Sustainability Science and Management, 6(1), pp.169178. 
PSYCHE: JURNAL PSIKOLOGI UNIVERSITAS MUHAMMADIYAH LAMPUNG

Vol.1 No.2, AGUSTUS 2019 ISSN 2655-6936 